\title{
Człowiek w obliczu choroby nowotworowej i śmierci
}

\section{Human facing cancerous disease and death}

\author{
MARIA ŻYGOWSKA ${ }^{1}$,GRAŻYNA CHOJNACKA-KOWALEWSKA ${ }^{2,3}$ \\ ${ }^{1}$ Hospicjum im. J Popiełuszki w Bydgoszczy \\ 2Instytut Nauk o Zdrowiu, Państwowa Wyższa Szkoła Zawodowa we Włocławku, \\ ${ }^{3}$ Wojewódzki Szpital Specjalistyczny im .J. Popiełuszki we Włocławku
}

DOI: http://dx.doi.org/10.21784/lwP.2017.007

ISSN: 2451-1846

\section{Streszczenie:}

Wstęp. Aktualna definicja WHO z 2002 roku mówi, że opieka paliatywna jest sposobem postępowania poprawiającym jakość życia pacjentów i ich rodzin stojących wobec problemów związanych $\mathrm{z}$ chorobą zagrażającą życiu, poprzez zapobieganie i łagodzenie cierpienia, wczesną identyfikację problemów, jak najlepszą ocenę i leczenie bólu oraz innych problemów fizycznych, psychosocjalnych i duchowych.

Opieka paliatywna opiera się $\mathrm{w}$ niewielkim stopniu na dowodach naukowych, ponieważ wiąże się to z licznymi problemami praktycznymi, etycznymi i emocjonalnymi. Istnieje etyczny nakaz świadczenia pacjentom najlepszej opieki. Jedynym jednak sposobem faktycznego poprawienia jakości opieki jest prowadzenie takich badań oraz wyciągnięcie odpowiednich wniosków celem poprawy tejże opieki nad chorym, a co za tym idzie poprawy jakości jego życia. W pracy przybliżono pojęcie choroby nowotworowej, scharakteryzowano niektóre problemy występujące w zaawansowanej chorobie nowotworowej, opisano charakter i zakres 
opieki paliatywnej, a także przybliżono problem jakości opieki nad chorymi przebywającymi na oddziałach paliatywnych, znacząco wpływający na jakość życia chorych.

Cel. Celem niniejszej pracy jest ocena jakości opieki na oddziale stacjonarnym hospicjum oraz zorientowanie się jakie czynniki mają wpływ na poprawę jakości życia chorych, a także wyciągnięcie odpowiednich wniosków celem poprawy jakości życia chorych i poprawy jakości opieki.

Wyniki. Analiza badań własnych dotyczy oceny jakości opieki na oddziale hospicjum, oraz wpływu tej opieki na jakość życia chorych.

Materiał i metody. W badaniach posłużono się metodą sondażu diagnostycznego. Narzędziem badawczym była ankieta własnej konstrukcji. Badaniem objęto dwie grupy osób. Pierwszą stanowiły rodziny chorych pacjentów przebywających na oddziale stacjonarnym hospicjum (50 osób). Drugą grupę stanowiła grupa wolontariuszy (52 osoby).

Wnioski. Na poprawę jakości opieki oraz jakości życia chorych wpływa sprawne i szybkie działanie całego zespołu interdyscyplinarnego, szybka reakcja na dolegliwości i problemy chorego w którego skład wchodzi: lekarz, pielęgniarka, ksiądz, psycholog, rehabilitant oraz wolontariusz

Analiza przeprowadzonych badań wykazała, że jakość opieki na oddziale stacjonarnym hospicjum jest na wysokim poziomie. Warto utrzymać nadal taki poziom opieki, ponieważ wpływa on w dużym stopniu na jakość życia chorych i ich lepsze funkcjonowanie w trudnej sytuacji życiowej.

Słowa kluczowe: opieka paliatywna, jakość życia, nowotwór

\begin{abstract}
:
Introduction. Current definition by WHO from 2002 defines palliative care as a way of acting that aims at enhancing the quality of patients' and their families' lives who face problems concerning a life-threatening disease. Those actions include: preventing and soothing pain, early identification of any problems, the best possible assessment and pain healing combined with curing other physical, psycho-social and mental problems.

Palliative care is only to a small extent based on scientific evidence as it is associated with numerous practical, ethical and emotional problems. There is an ethical imperative to provide patients with the best possible care. Nonetheless, the only possible way to improve the quality of palliative care is to conduct such scientific research and draw right conclusions that would
\end{abstract}


consequently lead to the improvement of patient care and therefore to the improvement of patients' lives. The paper describes the nature of cancer, characterizes particular issues occurring at its advanced stage and defines the character and scope of palliative care. It also covers the quality of medical care at the palliative wards which significantly affects lives of the patients who are treated there.

Aim. This paper is aimed at evaluating the quality of palliative care provided at a full-time ward of a hospice and defining the factors that are crucial for improving the quality of life of the sick as well as drawing right conclusions which will then result in improving palliative care and the quality of patients' lives.

Results. The analysis of our research regards the assessment of the quality of medical care at the hospice ward and its effect on the quality of patients' lives.

Material and methods. The research was based on a survey with the use of a questionnaire prepared by the author. The research included two groups of patients. The first group consisted of relatives of the patients treated at the full-time ward of the hospice (50 people). The second one consisted of volunteers (52 people).

Conclusions. The improvement of the quality of care as well as of patients' lives is affected by efficient and fast work of an interdisciplinary team that consists of a doctor, a nurse, a priest, a psychologist, a physiotherapist and a volunteer. The team is supposed to react quickly to the patient's complaints and problems.

The research analysis has indicated that the quality of the medical care at the full-time hospice ward is high level one. Such a high level is worth being sustained as it significantly affects patients' quality of lives and their better functioning in a difficult life situation.

Keywords: palliative care, quality of life, cancer

\section{Wstęp}

Żadna choroba nie wywołuje chyba takiego lęku jak rak. Przez społeczeństwo uważany jest za podstępną chorobę prowadzącą do degradacji organizmu i bolesnej, powolnej agonii. Wielu ludzi diagnozę raka odbiera jako wyrok śmierci, pomimo tego, że osiągnięto w medycynie znaczące postępy $\mathrm{w}$ badaniach nad opracowaniem metod terapii i usuwania raka [1]. Pełnoobjawowy nowotwór 
rozwinie się wtedy, gdy wystąpią kolejne mutacje genetyczne, których efektem będzie stopniowe powiększenie populacji komórek nowotworowych i nabywanie przez nie kolejnych atrybutów umożliwiających wzrost miejscowy, a potem ekspansję na otaczające tkanki rozsiew i zasiedlania odległych obszarów tkankowych (przerzutowania). Proces uzyskiwania wszystkich tych cech określamy mianem progresji nowotworu [2].

Krajowy konsultant w dziedzinie onkologii klinicznej - profesor Maciej Krzakowski zwraca uwagę, że dzięki badaniom genetycznym można stosować terapie dobrane indywidualnie dla konkretnego chorego i podtypu nowotworu [3].

Zaawansowana choroba nowotworowa niesie z sobą wiele dolegliwości, które są uciążliwe dla chorego i bardzo obniżają jakość jego życia. Tutaj wielką rolę odgrywa opieka paliatywna, która ma na celu poprawę jakości życia chorych i ich rodzin stających przed problemami związanymi $\mathrm{z}$ chorobą ograniczającą życie przez zapobieganie i łagodzenie cierpienia dzięki wczesnemu wykrywaniu, ocenie i leczeniu bólu i innych objawów fizycznych oraz problemów psychosocjalnych i duchowych (WHO, 2002) [4].

Chory jest osobą, do której należy decyzja jak chce przemierzyć, bez utraty godności, długą i trudną drogę prowadzącą do końca życia. Często uczucia i potrzeby chorego są odległe od naszych oczekiwań, modeli organizacyjnych i sposobów postępowania leczniczego.

Zapewnienie opieki paliatywnej chorym $\mathrm{w}$ terminalnym okresie choroby, który definiowany jest jako czas, w którym z dnia na dzień następuje pogorszenie stanu zdrowia, zwłaszcza utraty siły, apetytu i świadomości[5]. To wyzwanie dla opiekującego się nimi personelu także z psychologicznego punktu widzenia[6].

Ciężka choroba nowotworowa, umieranie i śmierć bliskich są wymieniane $\mathrm{w}$ badaniach socjologicznych jako sytuacje najbardziej trudne i stresujące $\mathrm{w}$ życiu człowieka. Ludzie nie radzą sobie 
z długotrwałym stresem wywołanym ciężką chorobą, nie radzą sobie również z nawarstwiającymi się codziennymi problemami.

Wśród bliskich jest duże zapotrzebowanie na rozmowy na temat cierpienia, umierania i śmierci. Rodziny chorych oczekują szeroko pojętego wsparcia od personelu medycznego, który sprawuje bezpośrednią opiekę nad chorym. Najsilniejszym źródłem wsparcia jest rodzina [7].

Chorym w przystosowaniu, przyjęciu do wiadomości, że pozostało już tylko leczenie objawowe pomagają mechanizmy obronne organizmu. W tej trudnej sytuacji dają one czas na oswojenie się, zaadoptowanie i poprawę stanu emocjonalnego, są także warunkiem dobrej lub lepszej jakości życia. Bardzo trudno jest sprecyzować granice między byciem chorym a umierającym. Umieranie jest ostatnią fazą choroby, w której stan się systematycznie pogarsza i nie ma szans na poprawę, natomiast śmierci można się spodziewać w ciągu kilku dni do kilkunastu miesięcy. Każdy człowiek ma swoją własną drogę ku śmierci. Mimo rozróżniania różnych faz umierania i śmierci może się okazać, że w żaden sposób nie można do chorego dotrzeć. Chory jest przygnębiony, skoncentrowany na przeszłości, ma ostre stany lękowe, wzmożoną drażliwość, nie interesuje go teraźniejszość i przyszłość. Takiemu choremu możemy dać wsparcie przez swoją troskliwą obecność, pamięć o nim w różnych sytuacjach. Bardzo ważne są tutaj relacje po prostu człowiek- człowiek [8].

Kiedy chory umiera, rozpoczyna się okres żałoby, który tak naprawdę rozpoczął się $\mathrm{w}$ dniu postawienia diagnozy: choroba nowotworowa.

Z badań przeprowadzonych przez M. Krasuską i wsp. wynika, że rodziny chorych nowotworowo oczekują od personelu medycznego szeroko pojętego wsparcia. Bardzo ważne są dla nich rozmowy na tematy śmierci i umierania.

Sytuacja chorego jest sytuacją beznadziejną, a rodzina potrzebuje wsparcia. Chce panować nad sytuacją i mieć wpływ na to co dzieje się wokół chorego, żeby radzić sobie z odczuciami, nabywać 
wiedzę odnośnie aktualnej sytuacji, móc lepiej wspierać chorego. $\mathrm{Z}$ badań tych wynika, że istnieją duże niedociągnięcia $w$ edukacji chorego i rodziny, dlatego też warto zwrócić na to szczególną uwagę [7].

W świetle reformy służby zdrowia problemy jakości opieki medycznej, w tym także paliatywnej nabierają szczególnego znaczenia. Procedury przyjęte i realizowane poprzez poszczególne jednostki służby zdrowia, będące konkretną formą świadczonych usług, wyznaczają konieczność ich sprawdzenia tak pod względem włożonych kosztów jak i uzyskanych efektów. Właściwym „efektem” usług medycznych jest dobra jakość opieki [9].

Istotnym czynnikiem efektywności opieki jest satysfakcja chorego ze sprawowanej opieki. Można ją opisać jako wartość określającą różnice między oczekiwaniami pacjenta, a stopniem ich zaspokojenia. Jeżeli różnica ta jest duża- poczucie satysfakcji jest niskie [10].

Udział rodziny w świadczeniu opieki paliatywnej jest bardzo ważny. Dobra współpraca $\mathrm{z}$ personelem medycznym również warunkują jakość opieki. Członkowie rodziny często lepiej dostrzegają potrzeby chorego i możliwości ich zaspokajania[11].Ważnym elementem opieki paliatywnej jest wolontariat, który w Polsce funkcjonuje od początku lat dziewięćdziesiątych XX wieku [12].

Nazwa „wolontariat” pochodzi od łacińskiego słowa voluntasdobra wola, dobrotliwość. Wolontariuszem nazywamy człowieka, który zdecydował się na bezinteresowne niesienie pomocy drugiemu człowiekowi. Wolontariusz to osoba, która chętnie i bez wynagrodzenia wykonuje pracę na rzesz danej instytucji czy organizacji. Wolontariat hospicyjny jest uzupełnieniem pracy pracowników hospicjum[13].

Człowiek, który znajdzie się w sytuacji bez wyjścia, dla którego diagnoza brzmi: choroba nowotworowa w zaawansowanym stadium bez możliwości dalszego leczenia, gdzie zostało tylko leczenie objawowe, powinien zostać objęty fachową, profesjonalną opieką 
hospicjum domowego lub stacjonarnego. To bardzo trudna sytuacja i czas dany człowiekowi na oswojenie się z chorobą, zaadoptowanie do nowej sytuacji oraz poprawę stanu emocjonalnego. Czynniki te są także warunkiem dobrej lub lepszej jakości życia. Każde życie człowieka jest wartością i zasługuje na traktowanie go z szacunkiem i poszanowaniem godności osobistej.

Podnoszenie jakości opieki w ośrodkach medycznych jest ważnym wyznacznikiem lepszej jakości życia chorych.

Celem pracy jest ocena jakości opieki na oddziale stacjonarnym hospicjum oraz zorientowanie się, jakie czynniki mają wpływ na poprawę jakości życia chorych, a także wyciągnięcie odpowiednich wniosków, celem poprawy jakości życia chorych i poprawy jakości opieki.

Dla celów analizy założono, że na jakość życia chorych wpływa podniesienie opieki pielęgniarskiej, lekarskiej i duchowej oraz psychologa, rehabilitanta i wolontariusza, a także umiejętność szybkiego i dostatecznego łagodzenia objawów, natomiast miernikiem poprawy jakości życia chorych jest podniesienie jakości opieki.

\section{Materiał i metody}

Badania były przeprowadzone na oddziale stacjonarnym Hospicjum im. J Popiełuszki w Bydgoszczy wśród wolontariuszy oraz rodzin chorych przebywających na oddziale hospicjum. Rozprowadzono 52 ankiet do wolontariuszy i uzyskano zwrot 52, oraz 50 ankiet wśród rodzin chorych i uzyskano zwrot 50 ankiet. Osoby te wyraziły zgodę na udział w badaniu.

Badane osoby to osoby w większości wykształcone. Dominuje wykształcenie średnie - 30 osób $(60,0 \%)$ i wykształcenie wyższe 14 osób (38,0\%).

Zarówno w grupie wolontariuszy jak i rodzin przewagę stanowiły kobiety, odpowiednio 78,8\% i 64\%. 
Zdecydowanie najliczniejszą grupę stanowili wolontariusze w wieku 61 - 80 lat $(61,5 \%)$, podobnie wśród rodzin najliczniejsza grupę stanowiły osoby w wieku 51-70 lat (62,0\%).

W czasie prowadzonych badań posłużono się kwestionariuszami ankiet własnej konstrukcji oraz dokonując analizy pytań kwestionariusza ankiety poddano go weryfikacji ze względu na zmienne socjodemograficzne, do których wytypowano płeć, grupy wiekowe i wykształcenie. W przypadku zmiennych grupa wiekowa i wykształcenie zastosowano test korelacji Spearmana, do zmiennej płeć zastosowano test U Manna- Whitneya.

\section{Wyniki}

Przedstawione wyniki opracowano na podstawie badań własnych i dokonano korelacji w zależności od badanych czynników socjodemograficznych.

\section{Analiza kwestionariusza -rodzina}

Tabela 1. Dolegliwości na które skarży się bliski chory.

\begin{tabular}{|l|r|r|}
\hline Dolegliwości & $\mathrm{n}$ & $\%$ \\
\hline ból & 14 & 11,8 \\
\hline duszność & 16 & 13,4 \\
\hline nudności & 2 & 1,7 \\
\hline wymioty & 2 & 1,7 \\
\hline zaparcia & 14 & 11,8 \\
\hline zmęczenie & 28 & 23,5 \\
\hline
\end{tabular}




\begin{tabular}{|l|r|r|}
\hline obrzęki & 15 & 12,6 \\
\hline lęk & 20 & 16,8 \\
\hline wypadanie włosów & 0 & 0,0 \\
\hline kaszel & 3 & 2,5 \\
\hline Inne & 5 & 4,2 \\
\hline Razem & 119 & 100,0 \\
\hline
\end{tabular}

Źródło: opracowanie własne

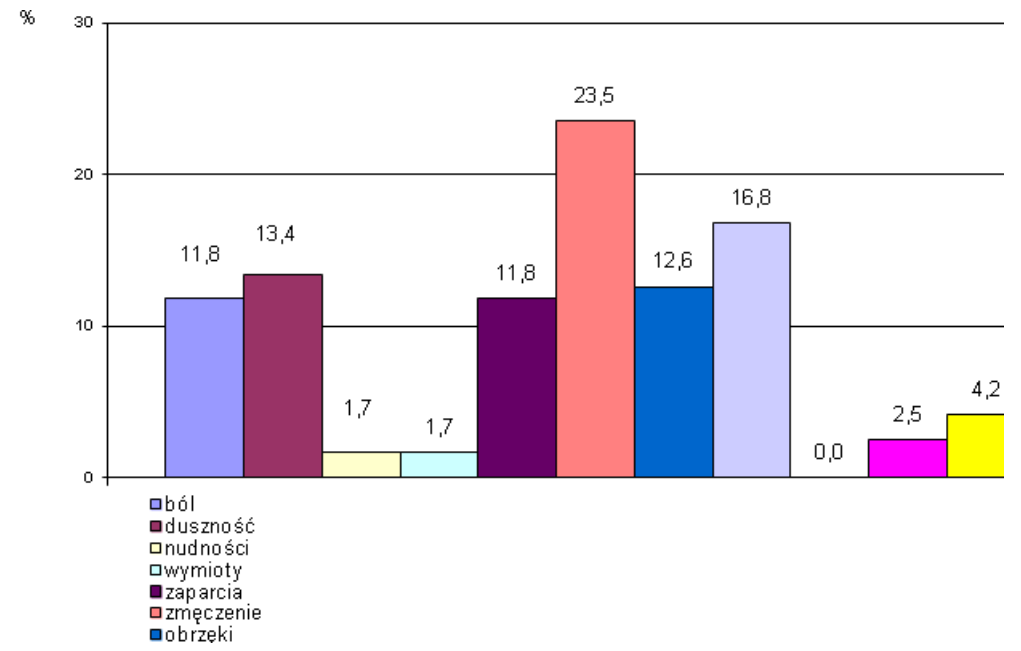

Rycina 1. Rozkład dolegliwości u chorych.

Źródło: opracowanie własne

Badane rodziny miały prawo wymienić więcej niż jedna dolegliwość na jaką cierpi badany. Łącznie zebrano 119 odpowiedzi. Najczęściej wymienianą dolegliwością okazało się zmęczenie, które 
wymieniło 28 osób a odpowiedź ta stanowiła 23,5\% wszystkich udzielonych odpowiedzi. W dalszej kolejności znalazł się lęk - 20 osób $(16,8 \%)$. Nieco mniej badanych wymieniło duszność - 16 osób (13,4\%), obrzęki - 15 osób (12,6\%) oraz ból i zaparcia - po 14 osób (po 11,8\%). Najmniej osób wskazało na nudności i wymioty - po 2 osoby (po 1,7\%). Nikt z badanych nie wymienił wypadania włosów. Wśród dolegliwości pod pozycją „inne” znalazły się odpowiedzi: po jednej osobie - biegunki i brak kontaktu z chorym oraz w trzech przypadkach depresja.

Tabela 2. Dostateczne łagodzenie dolegliwości chorego.

\begin{tabular}{|l|r|r|}
\hline Odpowiedź & $\mathrm{n}$ & $\%$ \\
\hline tak & 48 & 96,0 \\
\hline nie & 0 & 0,0 \\
\hline nie mam zdania na ten temat & 2 & 4,0 \\
\hline Razem & 50 & 100,0 \\
\hline
\end{tabular}

Źródło: opracowanie własne 


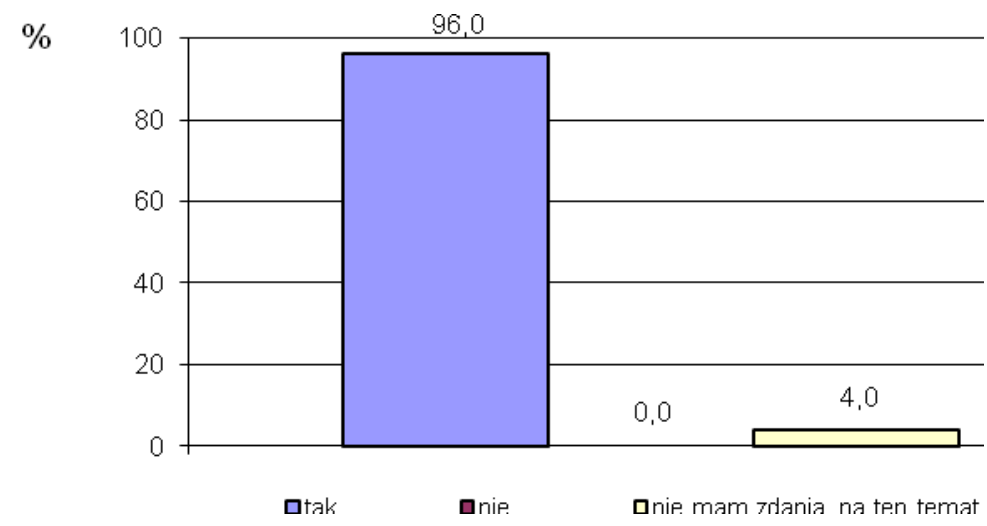

Rycina 2. Rozkład zdania o dostatecznym łagodzeniu dolegliwości u chorego.

Źródło: opracowanie własne

Dolegliwości chorego są dostatecznie łagodzone. Pozostali, byli w tym temacie zgodni twierdząc - „tak". Zaledwie 2 osoby $(4,0 \%)$ nie potrafiły ustosunkować się do tego stwierdzenia.

Tabela 3. Dostatecznie szybkie łagodzenie dolegliwości.

\begin{tabular}{|l|r|r|}
\hline Odpowiedź & n \\
\hline tak & 48 & 96,0 \\
\hline nie & 0 & 0,0 \\
\hline nie wiem & 2 & 4,0 \\
\hline Razem & 50 & 100,0 \\
\hline
\end{tabular}

Źródło: opracowanie własne 


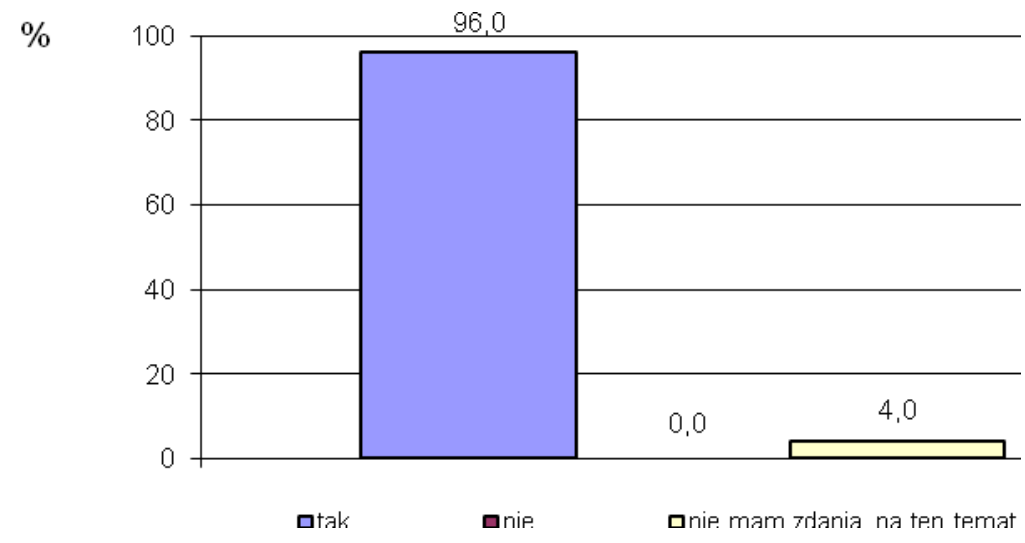

Rycina 3. Rozkład szybkiego łagodzenia dolegliwości u chorego. Źródło: opracowanie własne

Identyczną opinię wyrazili w kwestii szybkości łagodzenia dolegliwości u chorego. Zaledwie 2 osoby $(4,0 \%)$ nie potrafiły ustosunkować się do tego stwierdzenia. Pozostali byli w tym temacie zgodni twierdząc - „tak”.

Tabela 4. Wystarczająca i fachowa opieka pielęgniarska.

\begin{tabular}{|l|r|r|}
\hline Odpowiedź & $\mathrm{n}$ & $\%$ \\
\hline tak & 50 & 100,0 \\
\hline nie & 0 & 0,0 \\
\hline Razem & 50 & 100,0 \\
\hline
\end{tabular}

Źródło: opracowanie własne 
Wszystkie rodziny były zgodne, że opieka pielęgniarska jest wystarczająca, fachowa i odpowiedniej jakości.

Tabela 5. Wystarczająca, fachowa, odpowiedniej jakości opieka lekarska.

\begin{tabular}{|l|r|r|}
\hline Odpowiedź & $\mathrm{n}$ & $\%$ \\
\hline tak & 49 & 98,0 \\
\hline nie & 0 & 0,0 \\
\hline nie wiem & 1 & 2,0 \\
\hline Razem & 50 & 100,0 \\
\hline
\end{tabular}

Źródło: opracowanie własne

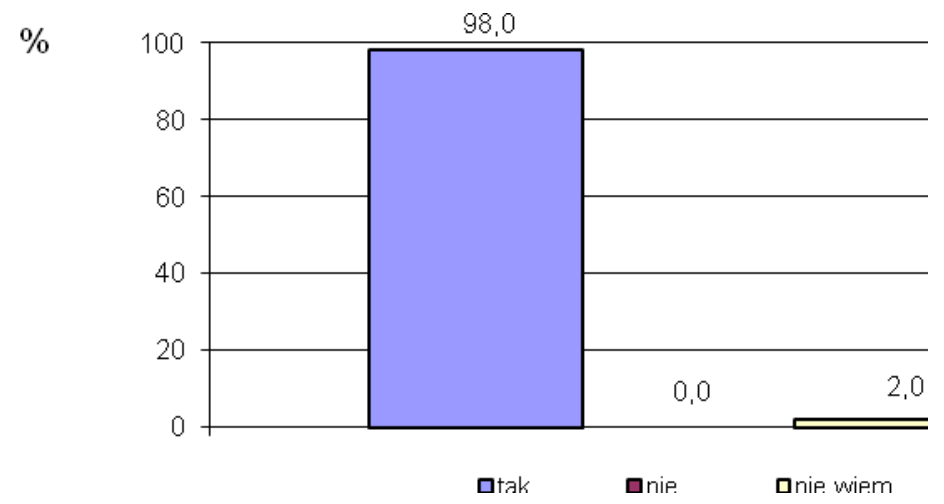

Rycina 4. Rozkład wystarczającej, fachowej i odpowiedniej jakości opieki lekarskiej.

Źródło: opracowanie własne 
Podobnie jest $\mathrm{z}$ opieka lekarską. Poza jedną z osób, która nie potrafiła się do tego pytania ustosunkować zaznaczając odpowiedź „nie wiem”.

Tabela 6. Wystarczająca, fachowa, odpowiedniej jakości opieka psychologa.

\begin{tabular}{|l|r|r|}
\hline Odpowiedź & $\mathrm{n}$ & $\%$ \\
\hline tak & 45 & 90,0 \\
\hline nie & 0 & 0,0 \\
\hline chory nie korzysta z opieki psychologa & 5 & 10,0 \\
\hline Razem & 50 & 100,0 \\
\hline
\end{tabular}

Źródło: opracowanie własne

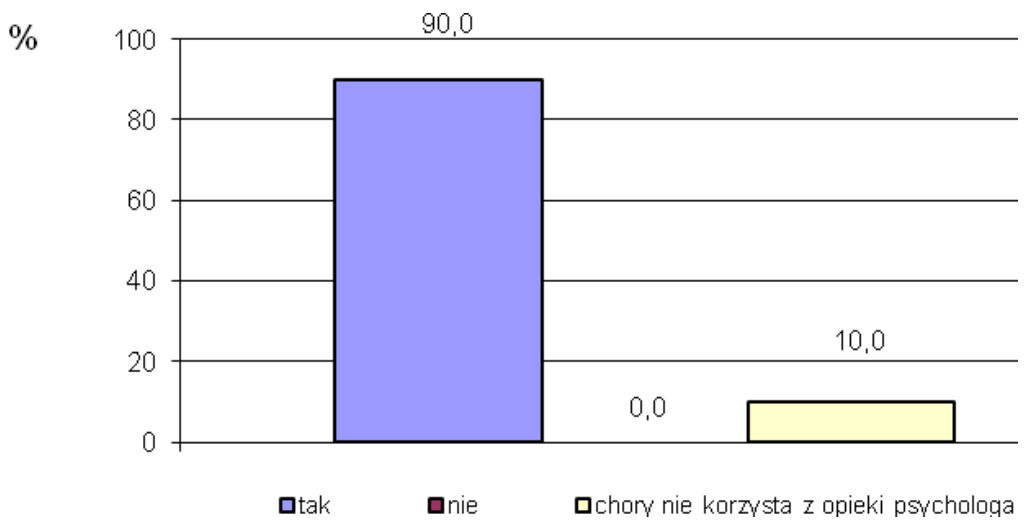

Rycina 5. Rozkład wystarczającej, fachowej, odpowiedniej jakości opieki psychologa.

Źródło: opracowanie własne 
Podobnie jest $\mathrm{z}$ opieką psychologa poza 5 osobami $(10,0 \%)$, które stwierdziły, że chory nie korzysta z opieki psychologa.

Tabela 7. Wystarczająca, fachowa, odpowiedniej jakości opieka rehabilitanta.

\begin{tabular}{|l|r|r|}
\hline Odpowiedź & $\mathrm{n}$ & $\%$ \\
\hline tak & 11 & 22,0 \\
\hline nie nie korzysta z pomocy & 1 & 2,0 \\
\hline $\begin{array}{l}\text { chory } \\
\text { rehabilitanta }\end{array}$ & 38 & 76,0 \\
\hline Razem & 50 & 100,0 \\
\hline
\end{tabular}

Źródło: opracowanie własne

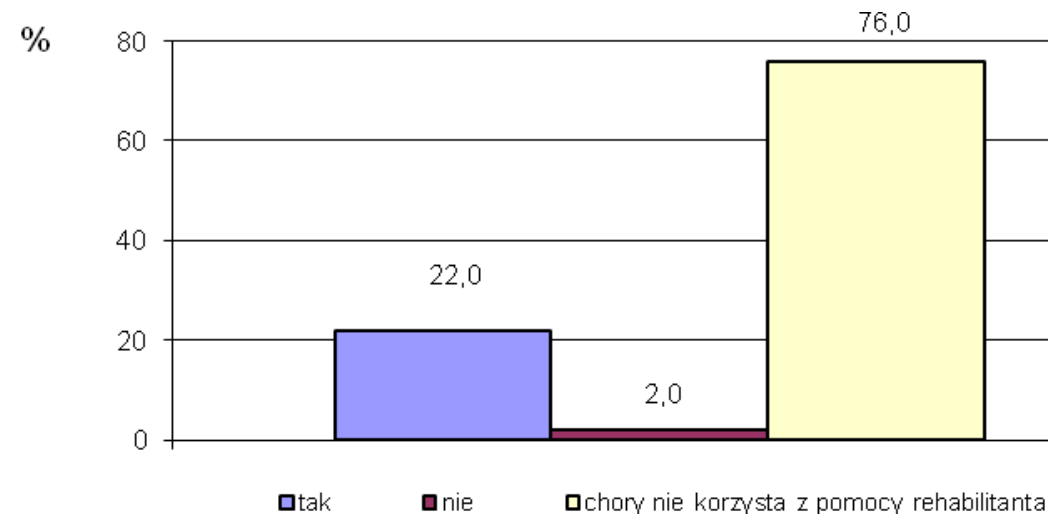

Rycina 6. Rozkład wystarczającej, fachowej, odpowiedniej jakości opieki rehabilitanta.

Źródło: opracowanie własne 
W przypadku opieki rehabilitanta większość z badanych twierdziła, że chory nie korzysta z opieki rehabilitanta - 38 osób $(76,0 \%)$. Z pozostałych osób jedna $(2,0 \%)$ stwierdziła, że opieka nie jest wystarczająca, fachowa i odpowiedniej jakości. Nie podała jednak podłoża takiej oceny.

Tabela 8. Wystarczająca opieka duchowa.

\begin{tabular}{|l|r|r|}
\hline Odpowiedź & $\mathrm{n}$ & $\%$ \\
\hline tak & 50 & 100,0 \\
\hline nie & 0 & 0,0 \\
\hline Razem & 50 & 100,0 \\
\hline
\end{tabular}

Źródło: opracowanie własne

Pełna zgodność, co do oceny duchowej. Wszyscy twierdzili, że jest ona wystarczająca.

Tabela 9. Wpływ na lepszą jakość opieki nad chorym.

\begin{tabular}{|l|r|r|}
\hline Czynnik & $\mathrm{n}$ & $\%$ \\
\hline fachowa pomoc i opieka lekarska & 0 & 0,0 \\
\hline fachowa pomoc i opiela pielęgniarska & 1 & 1,5 \\
\hline fachowa pomoc i opieka psychologa & 0 & 0,0 \\
\hline fachowa pomoc i opieka rehabilitanta & 0 & 0,0 \\
\hline pomoc i opieka duchowa & 1 & 1,5 \\
\hline
\end{tabular}




\begin{tabular}{|l|r|r|}
\hline $\begin{array}{l}\text { fachowa pomoc całego zespołu, w którego skład wchodzą } \\
\text { ksiądz, lekarz, pielęgniarka, psycholog, rehabilitant, } \\
\text { pracownik socjalny, wolontariusz }\end{array}$ & 47 & 72,3 \\
\hline $\begin{array}{l}\text { szybka reakcja na problemy i dolegliwości chorego całego } \\
\text { zespołu opiekującego się chorym }\end{array}$ & 16 & 24,6 \\
\hline inna opinia & 0 & 0,0 \\
\hline Razem & 65 & 100,0 \\
\hline
\end{tabular}

Źródło: opracowanie własne

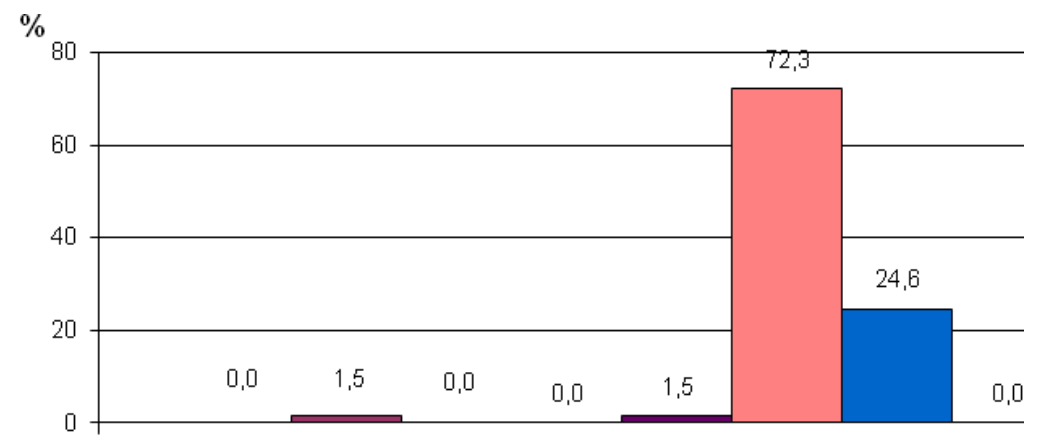

$\square$ fachowa pomoc i opieka lekarska

$\square$ fachowa pomoc i opiela pielęgniarska

$\square$ fachowa pomoc i opieka psychologa

$\square$ fachowa pomoc i opieka rehabilitanta

Rycina 7. Rozkład czynników wpływających na lepsza jakość opieki nad chorym.

Źródło: opracowanie własne

Odpowiadając na pytanie, o czynniki mające wpływ na jakość opieki nad chorym zebrano łącznie 65 odpowiedzi. zdecydowana 
większość badanych twierdziła, że fachowa pomoc całego zespołu, w którego skład wchodzą: ksiądz, lekarz, pielęgniarka, psycholog, rehabilitant, pracownik socjalny, wolontariusz - 47 osób, a odpowiedź ta stanowiła $72,3 \%$ wszystkich udzielonych odpowiedzi. W dalszej kolejności znalazło się stwierdzenie - szybka reakcja na problemy i dolegliwości chorego całego zespołu opiekującego się chorym - 16 osób (24,6\%). Pozostałe to odpowiedzi epizodyczne.

Tabela 10. Cechy osób pozytywnie wpływające na samopoczucie chorego i jego lepszą jakość życia w ciężkiej chorobie.

\begin{tabular}{|l|r|r|}
\hline Odpowiedź & $\mathrm{n}$ & $\%$ \\
\hline $\begin{array}{l}\text { fachowość, postępowanie według standardów } \\
\text { i procedur }\end{array}$ & 46 & 19,7 \\
\hline Życzliwość & 47 & 20,1 \\
\hline Uśmiech & 48 & 20,5 \\
\hline cierpliwość & 45 & 20,5 \\
\hline poświęcanie choremu więcej czasu & 0 & 19,2 \\
\hline inne & 234 & 0,0 \\
\hline Razem & & 100,0 \\
\hline
\end{tabular}

Zródto: opracowanie własne 


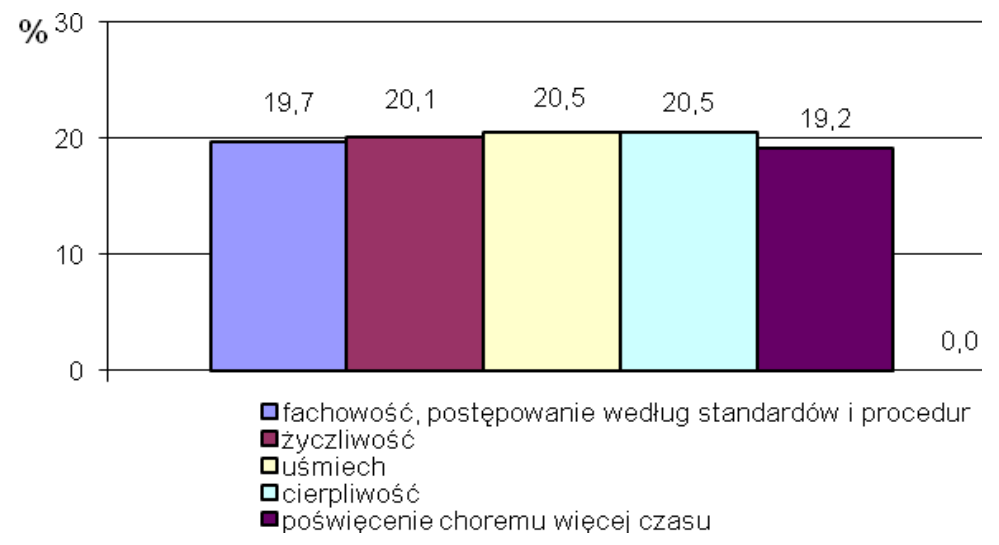

Rycina 8. Rozkład cech pozytywnie wpływających na samopoczucie i lepszą jakość życia chorego.

Źródło: opracowanie własne

W pytaniu tym badani mieli zhierarchizować cechy pozytywnie wpływające na samopoczucie chorego i przez to na jego lepszą jakość życia w chorobie. Niestety hierarchii takiej dokonało zaledwie 21 osób. Z pośród tych osób najwyżej oceniono uśmiech- średnia 3,6. W dalszej kolejności znalazła się życzliwość - średnia 3,3; cierpliwość - średnia 2,5; poświęcanie choremu więcej czasu - średnia 1,8 i fachowość, postępowanie według standardów i procedur - średnia 1,2. Biorąc pod uwagę wszystkie udzielone odpowiedzi, co znalazło swoje odzwierciedlenie w tabeli, zebrano łącznie 234 odpowiedzi. Najwięcej osób wymieniało właśnie uśmiech i cierpliwość - po 48 osób a odpowiedzi te stanowiły po $20,5 \%$ wszystkich udzielanych stwierdzeń. Najmniej razy wymieniono poświęcanie choremu więcej czasu - 45 osób (19,2\%). 
Tabela 11. Lepsze samopoczucie chorego dzięki opiece dobrej jakości.

\begin{tabular}{|l|r|r|}
\hline Odpowiedź & $\mathrm{n}$ & $\%$ \\
\hline tak & 47 & 94,0 \\
\hline nie & 0 & 0,0 \\
\hline nie wiem & 3 & 6,0 \\
\hline Razem & 50 & 100,0 \\
\hline
\end{tabular}

Źródło: opracowanie własne

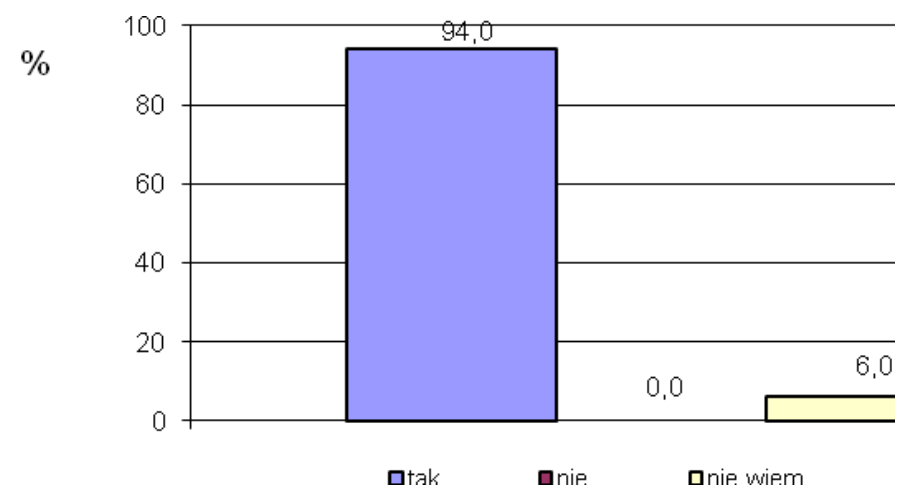

Rycina 9. Rozkład lepszego samopoczucia chorego dzięki dobrej opiece chorego.

Źródło: opracowanie własne

Badani w zdecydowanej większości uważali, że dzięki opiece dobrej jakości chory może czuć się lepiej- 47 osób (94,0\%). Pozostali nie mieli zdania w tym temacie. 
Tabela 12. Ewentualne zmiany i udoskonalenia wniesione do opieki nad chorym.

\begin{tabular}{|l|r|r|}
\hline Odpowiedź & $n$ & $\%$ \\
\hline wprowadzenie terapii zajęciowej & 1 & 2,0 \\
\hline opieka jest wspaniała & 1 & 2,0 \\
\hline nie jestem kompetentna & 1 & 2,0 \\
\hline nie mam zastrzeżeń & 1 & 2,0 \\
\hline wszystko w należytym porządku & 1 & 2,0 \\
\hline jestem bardzo zadowolona z opieki & 1 & 2,0 \\
\hline mają dobra opiekę & 1 & 2,0 \\
\hline jestem pełna uznania & 1 & 2,0 \\
\hline należy utrzymać obecny stan opieki & 1 & 2,0 \\
\hline żadnych & 1 & 2,0 \\
\hline opieka bardzo dobra, pełna poświęcenia & 1 & 2,0 \\
\hline brak odpowiedzi & 39 & 78,0 \\
\hline Razem & 50 & 100,0 \\
\hline Źrodto: opracowane własne & & \\
\hline
\end{tabular}

Źródło: opracowanie własne

Generalnie podając możliwość udoskonalenia opieki nad chorym, badani nie podali żadnej $\mathrm{z}$ możliwych zmian do 
wprowadzenia. Wszystkie udzielone odpowiedzi, to słowa pochwalne na temat opieki już istniejącej. Nie udzieliło odpowiedzi na to pytanie 39 osób (78,0\%).

Tabela 13. Ocena sprawowania opieki nad chorym w hospicjum.

\begin{tabular}{|l|r|r|}
\hline Ocena & $\mathrm{n}$ & $\%$ \\
\hline 1 & 0 & 0,0 \\
\hline 2 & 0 & 0,0 \\
\hline 3 & 0 & 0,0 \\
\hline 4 & 10 & 20,0 \\
\hline 5 & 40 & 80,0 \\
\hline Razem & 50 & 100,0 \\
\hline
\end{tabular}

Źródło: opracowanie własne

Oceniając sprawowanie opieki nad chorym w hospicjum istniały tylko dwie oceny - „4" i „5”. Najwięcej osób wystawiło ocenę „5" - 40 osób $(80,0 \%)$.

Tabela 14. Wystarczająca, fachowa, wystarczającej jakości opieka psychologa ze względu na wykształcenie.

\begin{tabular}{|l|r|r|r|r|r|r|}
\hline Wykształcenie & \multicolumn{2}{|r|}{$\begin{array}{r}\text { podstawowe/ } \\
\text { zawodowe }\end{array}$} & \multicolumn{3}{|r|}{ syższe } \\
\hline Odpowiedź & $\mathrm{n}$ & $\%$ & $\mathrm{n}$ & $\%$ & $\mathrm{n}$ & $\%$ \\
\hline tak & 4 & 66,7 & 27 & 90,0 & 14 & 100,0 \\
\hline
\end{tabular}




\begin{tabular}{|l|r|r|r|r|r|r|}
\hline nie & 0 & 0,0 & 0 & 0,0 & 0 & 0,0 \\
\hline $\begin{array}{l}\text { chory nie korzysta } \\
\text { z opieki psychologa }\end{array}$ & 2 & 33,3 & 3 & 10,0 & 0 & 0,0 \\
\hline Razem & 6 & 100,0 & 30 & 100,0 & 14 & 100,0 \\
\hline
\end{tabular}

Źródło: opracowanie własne

Stosunkowo najwięcej osób, którymi nie opiekuje się psycholog jest wśród badanych z wykształceniem podstawowym/ zawodowym2 osoby (33,3\%). Wśród badanych $\mathrm{z}$ wykształceniem wyższym wszyscy korzystają z pomocy psychologa.

\section{Analiza kwestionariusza-wolontariusz}

Tabela15. Rozumienie pojęcia dobrej jakości opieki.

\begin{tabular}{|l|r|r|}
\hline Odpowiedź & $\mathrm{n}$ & $\%$ \\
\hline $\begin{array}{l}\text { fachowa opieka nad chorym sprawowana przez } \\
\text { pielęgniarki }\end{array}$ & 11 & 9,6 \\
\hline fachowa opieka nad chorym sprawowana przez lekarza & 6 & 5,3 \\
\hline szybka reakcja na problemy i dolegliwości chorego & 21 & 18,4 \\
\hline Życzliwość & 20 & 17,5 \\
\hline przestrzeganie standardów i procedur w oddziale & 5 & 4,4 \\
\hline $\begin{array}{l}\text { fachowa opieka nad chorym całego zespołu w którego } \\
\text { skład wchodzą lekarze, pielęgniarki, ksiądz, psycholog, } \\
\text { rehabilitant, opiekunki, pracownicy gospodarczo- } \\
\text { socjalni, wolontariusze }\end{array}$ & 48 & 42,1 \\
\hline
\end{tabular}




\begin{tabular}{|l|r|r|}
\hline inna opinia & 3 & 2,6 \\
\hline Razem & 114 & 100,0 \\
\hline
\end{tabular}

Źródło: opracowanie własne

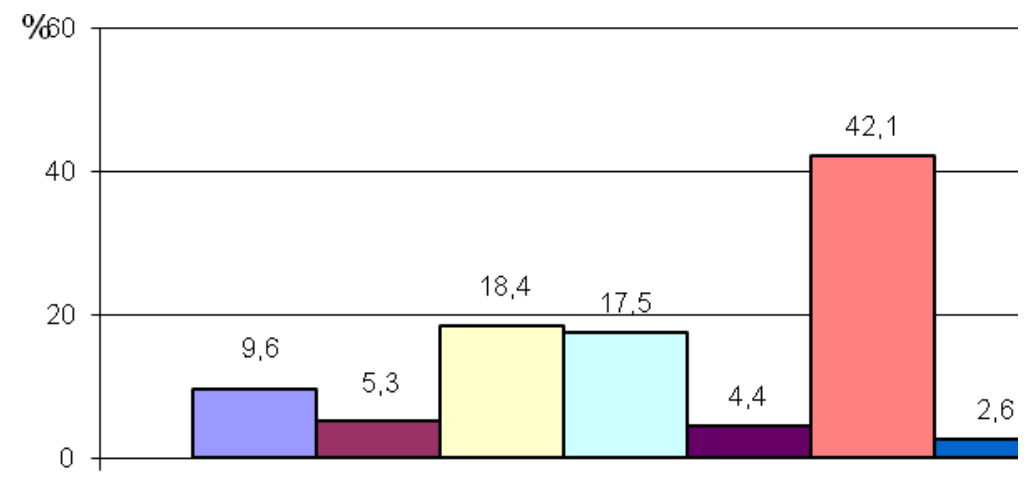

口fachowa opieka nad chorym sprawowana przez pielęgniarki

afachowa opieka nad chorym sprawowana przez lekarza

$\square$ szybka reakcja na problemy i dolegliwości chorego

口ìczliwość

口przestrzeganie standardów i procedur w oddziale

口fachowa opieka nad chorym całego zespołu

口inna opinia

Rycina 10. Rozkład rozumienia pojęcia dobrej jakości opieki.

Źródło: opracowanie własne

Odpowiadając na pytanie, o rozumienie pojęcia dobrej jakości życia zebrano łącznie 114 odpowiedzi. Zdecydowana większość wolontariuszy twierdziła, że poprzez dobrą jakość opieki rozumie przede wszystkim fachową pomoc całego zespołu, w którego skład wchodzą ksiądz, lekarz, pielęgniarka, psycholog, rehabilitant, pracownik socjalny, wolontariusz - 48 osób, a odpowiedź ta stanowiła $42,1 \%$ wszystkich udzielonych odpowiedzi. W dalszej kolejności 
znalazło się stwierdzenie - szybka reakcja na problemy i dolegliwości chorego - 21 osób $(18,4 \%)$ oraz życzliwość - 20 osób $(17,5 \%)$. W najmniejszym stopniu przestrzeganie standardów i procedur w oddziale - 5 osób $(4,4 \%)$.

Tabela 16. Czynniki wpływające na jakość opieki w hospicjum.

\begin{tabular}{|l|r|r|}
\hline Odpowiedź & $\mathrm{n}$ & $\%$ \\
\hline fachowa opieka & 27 & 11,6 \\
\hline $\begin{array}{l}\text { szybka reakcja na problemy i dolegliwości chorego ze } \\
\text { strony personelu }\end{array}$ & 41 & 17,6 \\
\hline rozmowa z chorym & 29 & 12,4 \\
\hline $\begin{array}{l}\text { pomoc w pracach gospodarczo- kuchennych, składanie } \\
\text { ligniny ... }\end{array}$ & 15 & 6,4 \\
\hline $\begin{array}{l}\text { pomoc pielęgniarkom przy czynnościach pielęgnacyjno- } \\
\text { higienicznych }\end{array}$ & 20 & 8,6 \\
\hline pomoc przy karmieniu chorych & 22 & 9,4 \\
\hline $\begin{array}{l}\text { pomoc przy aktywizowaniu chorych (sadzanie na wózek, } \\
\text { wożenie chorych, werandowanie ...) }\end{array}$ & 23 & 9,9 \\
\hline dobrze wykształcony personel & 18 & 7,7 \\
\hline obecność wolontariuszy i aktywność & 35 & 15,0 \\
\hline inne czynniki & 3 & 1,3 \\
\hline Razem & 233 & 100,0 \\
\hline Zrod o: opracowanie whas & & \\
\hline
\end{tabular}

Źródło: opracowanie własne 


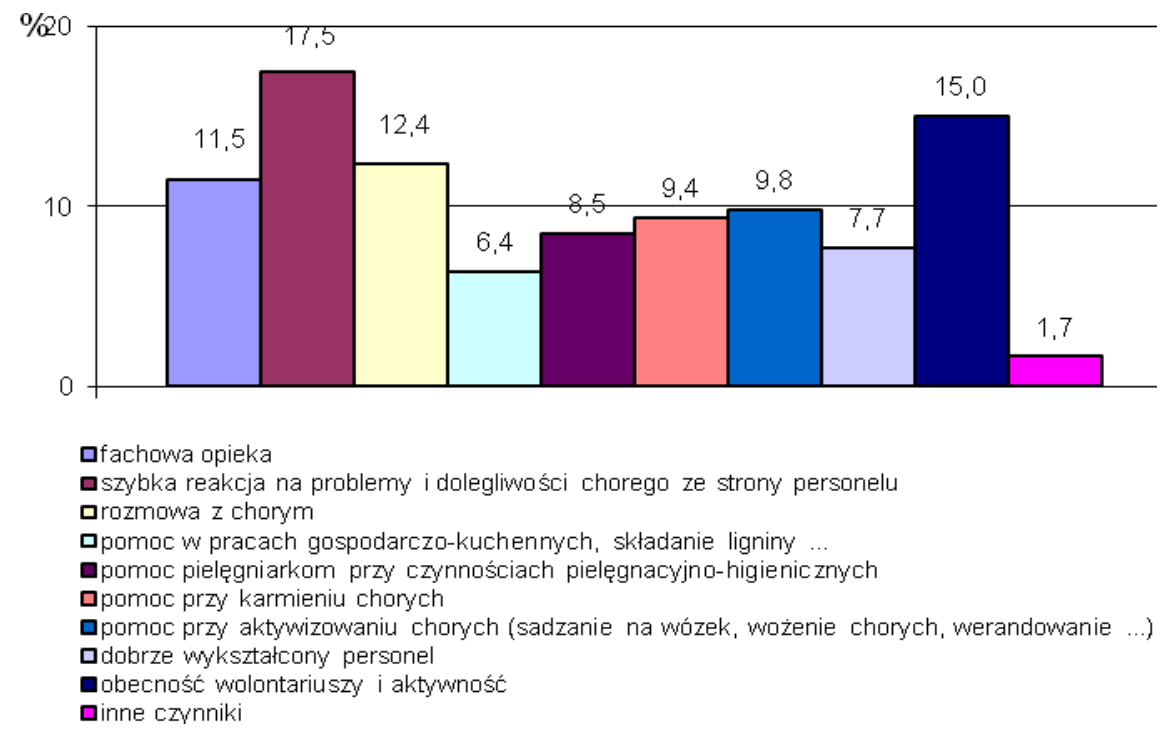

\section{Rycina 11. Rozkład czynników wpływających na jakość opieki whospicjum. \\ Źródło: opracowanie własne}

Odpowiadając na pytanie o czynniki wpływające na jakość opieki w hospicjum zebrano łącznie 234 odpowiedzi. Zdecydowana większość wolontariuszy twierdziła, że czynnikiem, który najbardziej wpływa na jakość opieki w hospicjum jest szybka reakcja na problemy i dolegliwości chorego ze strony personelu - 41 osób, a odpowiedź ta stanowiła $17,6 \%$ wszystkich udzielonych odpowiedzi. W dalszej kolejności znalazło się stwierdzenie - obecność wolontariuszy i aktywność - 35 osób $(15,0 \%)$ oraz rozmowa z chorym - 29 osób $(12,4 \%)$. 
Tabela 17. Osoby mające największy wpływ na podnoszenie jakości opieki nad chorym.

\begin{tabular}{|l|r|r|}
\hline Osoba & $\mathrm{n}$ & $\%$ \\
\hline wolontariusze & 28 & 14,1 \\
\hline lekarze & 34 & 17,2 \\
\hline pielęgniarki & 52 & 26,3 \\
\hline psycholog & 32 & 16,2 \\
\hline rehabilitant & 20 & 10,1 \\
\hline ksiądz & 27 & 13,6 \\
\hline inne osoby & 5 & 2,5 \\
\hline Razem & 198 & 100,0 \\
\hline
\end{tabular}

Źródło: opracowanie własne 


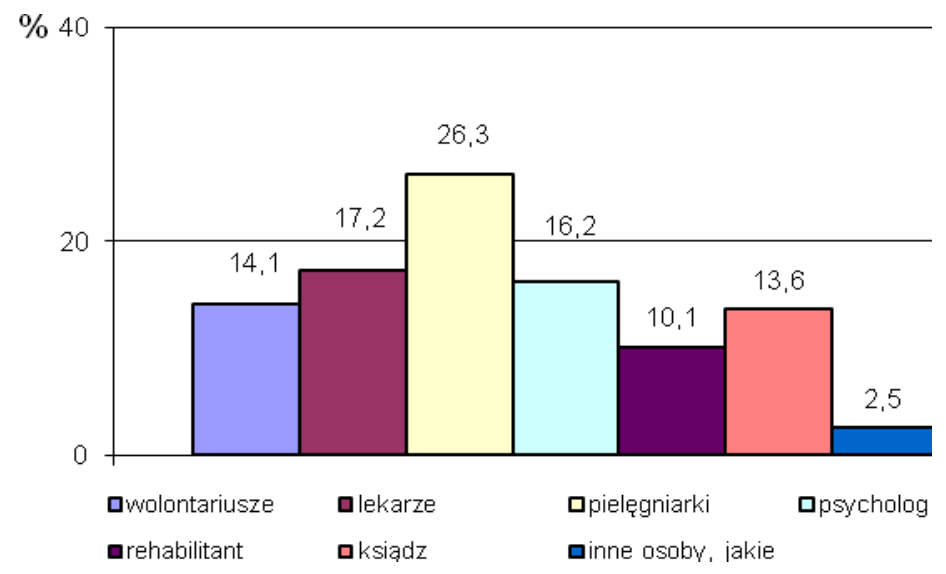

Rycina 12. Rozkład osób mających największy wpływ na podnoszenie jakości opieki nad chorym.

Źródło: opracowanie własne

Odpowiadając na pytanie o osoby, które mają największy wpływ na podnoszenie jakości opieki nad chorym zebrano łącznie 198 odpowiedzi. Zdecydowanie i w jednoznacznym stopniu wolontariusze wskazali na pielęgniarkę jako osobę, od której w największym stopniu zależy podnoszenie jakości opieki nad chorym - 50 osób, a odpowiedź ta stanowiła 26,3\% wszystkich udzielonych odpowiedzi. W dalszej kolejności znalazł się lekarz- 34 osoby $(17,2 \%)$ oraz psycholog - 32 osoby (16,2\%). W najmniejszym stopniu wskazano na rehabilitanta - 20 osób $(10,1 \%)$. Pod pojęciem „inna osoba" badani wolontariusze stwierdzili: pracownik socjalny i rodzina. Dwie osoby nie sprecyzowały odpowiedzi.

Tabela 18. Spełnianie pozytywnej roli przez wolontariuszy.

\begin{tabular}{|l|r|r|}
\hline Odpowiedź & $\mathrm{n}$ & $\%$ \\
\hline tak & 46 & 88,5 \\
\hline
\end{tabular}




\begin{tabular}{|l|r|r|}
\hline nie & 6 & 11,5 \\
\hline Razem & 52 & 100,0 \\
\hline
\end{tabular}

Źródło: opracowanie własne

$\%$

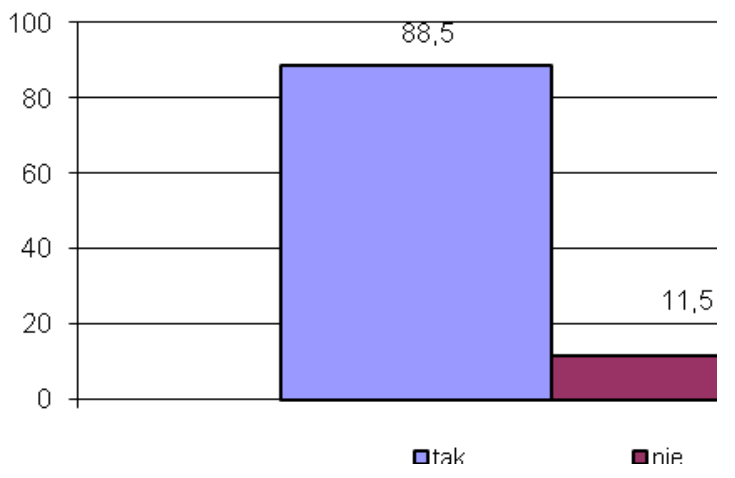

Rycina 13. Rozkład spełniania swojej roli przez wszystkich wolontariuszy w hospicjum.

Źródło: opracowanie własne

Nie wszyscy wolontariusze $\mathrm{z}$ hospicjum spełniają swoją rolę zdaniem 6 badanych $(11,5 \%)$. Swoje uzasadnienie podały tylko trzy osoby: często wolontariusze szukają drogi dla siebie, wyobrażenie jest inne, inna rzeczywistość, nie każdy wolontariusz nadaje się do tego by sprawować opiekę nad chorym i ingerują w sprawy, które nie leżą w ich kompetencjach.

Tabela 19. Zmiany polepszające opiekę nad chorym. 


\begin{tabular}{|c|c|c|}
\hline Zmiany & $\mathrm{n}$ & $\%$ \\
\hline $\begin{array}{l}\text { kursy i rozmowy z psychologiem co do postępowania } \mathrm{z} \\
\text { pacjentem trudnym, np ograniczonym, lub jak rozmawiać z } \\
\text { rodziną }\end{array}$ & 1 & 1,9 \\
\hline mniej papierkowej pracy & 1 & 1,9 \\
\hline $\begin{array}{l}\text { można zorganizować szkolenie dla rodzin pacjentów w } \\
\text { hospicjum, aby bliżej zapoznały się z zagadnieniem } \\
\text { choroby nowotworowej, wiedza na temat objawów, opieki } \\
\text { w chorobie, umierania }\end{array}$ & 1 & 1,9 \\
\hline nie mam zdania w związku z wciąż nikłym doświadczeniem & 1 & 1,9 \\
\hline nie wiem, nie zauważyłam, żeby chorym czegoś brakowało & 1 & 1,9 \\
\hline nie zastanawiałem się & 2 & 3,8 \\
\hline 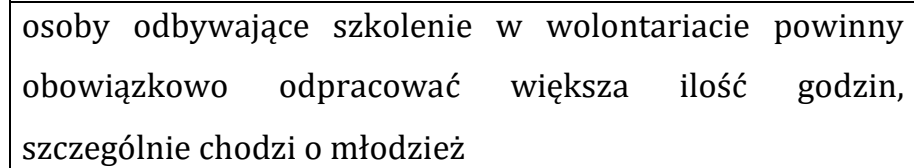 & 1 & 1,9 \\
\hline podnosić kwalifikacje wolontariuszy & 1 & 1,9 \\
\hline $\begin{array}{l}\text { potrzeba spotkań z chorymi, żeby chorzy mieli na nich } \\
\text { zajęcia, żeby czuli sie potrzebni }\end{array}$ & 1 & 1,9 \\
\hline $\begin{array}{l}\text { rozmowy na korytarzu powinny być wyciszone, } \\
\text { przeszkadza to chorym, winny być zawieszone napisy } \\
\text { "zachowuj ciszę", przy każdym łóżku winno być krzesło dla } \\
\text { odwiedzającego, trzeba je szukać po innych pokojach }\end{array}$ & 1 & 1,9 \\
\hline $\begin{array}{l}\text { trzeba się głębiej pochylić nad łóżkiem chorego (jak św. } \\
\text { Franciszek), trzeba z sobą przynosić więcej miłości, pokory } \\
\text { i cierpliwości }\end{array}$ & 1 & 1,9 \\
\hline
\end{tabular}




\begin{tabular}{|c|c|c|}
\hline $\begin{array}{l}\text { więcej czasu poświęcić na wymianę doświadczeń } \mathrm{z} \\
\text { personelem i chorymi w miarę możliwości }\end{array}$ & 1 & 1,9 \\
\hline więcej pielęgniarek, wolontariuszy i opiekunek & 3 & 5,8 \\
\hline $\begin{array}{l}\text { właściwa współpraca pomiędzy } \text { pielęgniarkami a } \\
\text { wolontariuszami }\end{array}$ & 1 & 1,9 \\
\hline $\begin{array}{l}\text { wyodrębnić miejsce o charakterze świetlica, duży TV, } \\
\text { projektor, duże akwarium, rośliny }\end{array}$ & 1 & 1,9 \\
\hline $\begin{array}{l}\text { zbyt rutynowe podejście pielęgniarki, może większa } \\
\text { selekcja przy zatrudnieniu, może szkolenie dla pielęgniarek } \\
\text { przez psychologa }\end{array}$ & 1 & 1,9 \\
\hline $\begin{array}{l}\text { życzliwość i atmosfera w hospicjum jest najwyższej jakości, } \\
\text { sądzę, że ciągła obecność } 1 \text { - } 2 \text { wolontariuszy na oddziale } \\
\text { usprawnia prace pielęgniarkom, dlatego byłoby dobrze } \\
\text { gdyby ktoś z nich był }\end{array}$ & 1 & 1,9 \\
\hline brak odpowiedzi & 32 & 61,5 \\
\hline Razem & 52 & 100,0 \\
\hline
\end{tabular}

Źródło: opracowanie własne

Odpowiedzi na pytanie dotyczące ewentualnych zmian jakie można wprowadzić, żeby jakość opieki nad chorym była jeszcze lepsza udzieliło zaledwie 20 osób (38,5\%). Z pośród tych osób 2 badanych $(3,8 \%)$ stwierdziło iż nie mają zdania w związku z wciąż nikłym doświadczeniem oraz nie wiem, nie zauważyłam, żeby chorym czegoś brakowało. Kolejne 2 osoby $(3,8 \%)$ twierdziły, że się nie zastanawiały nad zmianami, a następne 3 osoby $(5,8)$ twierdziły, że należy zwiększyć ilość pielęgniarek, opiekunek i wolontariuszy. Pozostałe to odpowiedzi jednostkowe wynikające $\mathrm{z}$ indywidualnych 
spostrzeżeń i nie można dopatrzeć się wśród nich zbieżności, czy prawidłowości.

Tabela 20. Ocena jakości opieki w hospicjum.

\begin{tabular}{|l|r|r|}
\hline Ocena & $\mathrm{n}$ & $\%$ \\
\hline 1 & 0 & 0,0 \\
\hline 2 & 0 & 0,0 \\
\hline 3 & 0 & 0,0 \\
\hline 4 & 18 & 34,6 \\
\hline 5 & 34 & 65,4 \\
\hline Razem & 52 & 100,0 \\
\hline
\end{tabular}

Źródło: opracowanie własne

Oceniając jakość opieki nad chorym w hospicjum wolontariusze stawiali tylko dwie oceny - „4” i „5”. Najwięcej osób wystawiło ocenę „5" - 34 osoby $(65,4 \%)$.

\section{Dyskusja}

Człowiek w kontekście choroby nowotworowej, znajdujący się w hospicjum to osoba znajdująca się w bardzo trudnym położeniu. Badania jakości życia chorych oraz jakości opieki zajmują szczególne miejsce w opiece paliatywnej i w onkologii. W związku z faktem, że chorzy w opiece paliatywnej znajdują się $\mathrm{w}$ zaawansowanym stadium choroby, gdzie poszczególne fazy choroby wiążą się z ogromem emocji, lękiem, cierpieniem fizycznym i psychicznym, a także z bólem egzystencjalnym, w badaniach własnych badaniu poddano nie samych chorych, ale najbliższą rodzinę chorego oraz osoby posługujące 
chorym w ramach wolontariatu. Rodziny chorych i wolontariusze to często dobrzy obserwatorzy, którzy bardzo trafnie oceniają jakość opieki i rozwiązania, które mogłyby mieć wpływ na jej polepszenie. Z badań własnych wynika, że największą rolę w podnoszeniu jakości opieki na oddziale stacjonarnym hospicjum odgrywają pielęgniarki. Zdecydowanie i w jednoznacznym stopniu wolontariusze wskazali na pielęgniarkę jako osobę od której w największym stopniu zależy podnoszenie jakości opieki nad chorym - 50 osób, a odpowiedź ta stanowiła 26,3\% wszystkich udzielonych odpowiedzi. Również w badaniach Krasuckiej M. i innych, jeżeli chodzi o opiekę i wsparcie dla chorych były to pielęgniarki. Tak twierdziło 18 badanych rodzin, co stanowiło $60 \%$ badanych. Jest to bardzo dobrze świadczący fakt o tej grupie zawodowej [7].

Jednym $\mathrm{z}$ bardzo uciążliwych objawów dla chorych onkologicznie jest zmęczenie. Pyszora A. w swoim artykule przedstawia aktualny stan wiedzy, oparty na wynikach badań klinicznych dotyczących wykorzystania i efektywności procedur fizjoterapeutycznych jako jednego z elementów nie farmakologicznego leczenia zmęczenia, które związane jest z chorobą nowotworową[14].

Jak twierdzi Davis i wsp., występuje ono u 20-30\% wyleczonych osób z długoletnim przeżyciem oraz u 80-90\% chorych leczonych przeciwnowotworowo lub $\mathrm{w}$ zaawansowanym stadium choroby [15].

Badania opublikowane na internetowej stronie czasopisma New England Journal of Medicine trwały trzy lata. Wzięło w nich udział 151 osób. Były to osoby $\mathrm{z}$ rakiem płuc ze szpitala w Massachusetts General. Część pacjentów poddano tylko leczeniu onkologicznemu, część leczeniu onkologicznemu połączonemu z opieką paliatywną. Opieka paliatywna polegała na podawaniu środków przeciwbólowych, a także innych środków, które miały poprawić jakość życia chorych. Chorzy od początku poddani opiece paliatywnej byli szczęśliwsi i mniej przygnębieni. W badaniach brano pod uwagę: ból, mdłości, aktywność, zmartwienie i inne problemy. 
Chorzy poddani opiece paliatywnej żyli około trzech miesięcy dłużej niż poddani standardowej opiece. Teoria autorów badań brzmi: jednym z czynników skracającym życie jest depresja, a pacjenci, których ból jest leczony śpią lepiej, lepiej jedzą i więcej rozmawiają z krewnymi, dzięki temu jakość ich życia jest lepsza [16].

Z badań własnych wynika, że najczęściej wymienianą dolegliwością okazało się zmęczenie, które wymieniło 28 osób, a odpowiedź ta stanowiła $23,5 \%$ wszystkich udzielonych odpowiedzi. W dalszej kolejności znalazł się lęk - 20 osób (16,8\%). Nieco mniej badanych wymieniło duszność - 16 osób (13,4\%), obrzęki - 15 osób $(12,6 \%)$ oraz ból i zaparcia - po 14 osób (po 11,8\%). Najmniej osób wskazało na nudności i wymioty - po 2 osoby (po 1,7\%). Nikt $\mathrm{z}$ badanych nie wymienił wypadania włosów. Wśród dolegliwości pod pozycją „inne” znalazły się odpowiedzi: po jednej osobie - biegunki i brak kontaktu $\mathrm{z}$ chorym oraz $\mathrm{w}$ trzech przypadkach depresja.

Wydawałoby się, że dominującymi dolegliwościami w chorobie nowotworowej jest ból i depresja. Te objawy jednak bliscy chorych wymieniają w dalszej kolejności. Można z tego wysnuć wniosek, że na oddziale hospicjum objawy te są łagodzone w sposób prawidłowy. Na pytanie czy objawy chorobowe są dostatecznie i szybko łagodzone 48 osób (96\%) pytanych odpowiedziało - „tak”. Ten fakt wpływa również na lepszą jakość życia chorych.

Dobra współpraca z personelem medycznym również warunkuje lepszą jakość opieki. Członkowie rodziny często lepiej dostrzegają potrzeby chorego i możliwości ich zaspokajania.

Z badań A. Przyłuskiej- Fiszer oraz A. Wójcik wynika, że chorzy poddawani rehabilitacji wyrażali werbalnie swoje zadowolenie z lepszego poziomu sprawności,

$\mathrm{w}$ danym momencie prezentowali duży poziom wewnętrznej nadziei. Analizując wyniki badań należy jednak wziąć pod uwagę, że w zaawansowanym stadium choroby nowotworowej sam wzrost sprawności nie jest w stanie zatrzymać postępu choroby [17]. Myślę, że 
warto jednak dla okresowej poprawy jakości życia chorych podjąć się rehabilitacji.

W badaniach własnych $\mathrm{w}$ przypadku opieki rehabilitanta większość z badanych twierdziła, że chory nie korzysta z opieki rehabilitanta - 38 osób (76,0\%). Wynikało to z faktu ciężkiego stanu chorych.

W badaniach własnych w odpowiedziach na pytanie bliskich chorych, o czynniki mające wpływ na jakość opieki nad chorym, zebrano łącznie 65 odpowiedzi. zdecydowana większość badanych twierdziła, że fachowa pomoc całego zespołu, w którego skład wchodzą ksiądz, lekarz, pielęgniarka, psycholog, rehabilitant, pracownik socjalny, wolontariusz- 47 osób a odpowiedź ta stanowiła $72,3 \%$ wszystkich udzielonych odpowiedzi. Również wolontariusze byli w większości zgodni co do takiej odpowiedzi. Było to 48 osób, a odpowiedź ta stanowiła $42,1 \%$ wszystkich udzielonych odpowiedzi.

Oliver D. w swoim artykule twierdzi, że zespół interdyscyplinarny jest podstawą opieki paliatywnej. Jeżeli pracuje prawidłowo, w znacznym stopniu poprawia jakość opieki nad pacjentem i jego rodziną[18].

Rodziny chorych oceniając sprawowanie opieki nad chorym w hospicjum staniały tylko dwie oceny - „4” i „5”. Najwięcej osób wystawiło ocenę „5” - 40 osób $(80,0 \%)$. Ocena średnia ze sprawowania opieki to 4,8 . Bliscy chorych uważali, że w opiece nie należałoby nic zmieniać, że jest najwyższej jakości. Jedna tylko z badanych stwierdziła, że dobrze byłoby wprowadzić terapię zajęciową dla poprawy samopoczucia chorych. Wolontariusze oceniając jakość opieki nad chorym w hospicjum stawiali tylko dwie ocen - „4” i „5”. Najwięcej osób wystawiło ocenę „5 - 34 osoby $(65,4 \%)$. 
Tabela 21. Zmiany polepszające opiekę nad chorym.

\begin{tabular}{|c|c|c|}
\hline Zmiany & $\mathrm{n}$ & $\%$ \\
\hline $\begin{array}{l}\text { kursy i rozmowy z psychologiem co do postępowania } \mathrm{z} \text { pacjentem } \\
\text { trudnym, np ograniczonym, lub jak rozmawiać } \mathrm{z} \text { rodziną }\end{array}$ & 1 & 1,9 \\
\hline mniej papierkowej pracy & 1 & 1,9 \\
\hline $\begin{array}{l}\text { można zorganizować szkolenie dla rodzin pacjentów w hospicjum, aby } \\
\text { bliżej zapoznały się z zagadnieniem choroby nowotworowej, wiedza } \\
\text { na temat objawów, opieki w chorobie, umierania }\end{array}$ & 1 & 1,9 \\
\hline nie mam zdania w związku z wciąż nikłym doświadczeniem & 1 & 1,9 \\
\hline nie wiem, nie zauważyłam, żeby chorym czegoś brakowało & 1 & 1,9 \\
\hline nie zastanawiałem się & 2 & 3,8 \\
\hline $\begin{array}{l}\text { osoby odbywające szkolenie w wolontariacie powinny obowiązkowo } \\
\text { odpracować większa ilość godzin, szczególnie chodzi mi o młodzież }\end{array}$ & 1 & 1,9 \\
\hline podnosić kwalifikacje wolontariuszy & 1 & 1,9 \\
\hline $\begin{array}{l}\text { potrzeba spotkań z chorymi żeby chorzy mieli na nich zajęcia, żeby } \\
\text { czuli sie potrzebni }\end{array}$ & 1 & 1,9 \\
\hline $\begin{array}{l}\text { rozmowy na korytarzu powinny być wyciszone, przeszkadza to } \\
\text { chorym, winny być zawieszone napisy "zachowuj ciszę", przy każdym } \\
\text { łóżku winno być krzesło dla odwiedzającego, trzeba je szukać po } \\
\text { innych pokojach }\end{array}$ & 1 & 1,9 \\
\hline $\begin{array}{l}\text { trzeba się głębiej pochylić nad łóżkiem chorego(jak św Franciszek), } \\
\text { trzeba z sobą przynosić więcej miłości, pokory i cierpliwości }\end{array}$ & 1 & 1,9 \\
\hline $\begin{array}{l}\text { więcej czasu poświęcić na wymianę doświadczeń z personelem i } \\
\text { chorymi w miarę możliwości }\end{array}$ & 1 & 1,9 \\
\hline więcej pielęgniarek, wolontariuszy i opiekunek & 3 & 5,8 \\
\hline właściwa współpraca pomiędzy pielęgniarkami a wolontariuszami & 1 & 1,9 \\
\hline
\end{tabular}




\begin{tabular}{|c|c|c|}
\hline $\begin{array}{l}\text { wyodrębnić miejsce o charakterze świetlica, duży TV, projektor, duże } \\
\text { akwarium, rośliny }\end{array}$ & 1 & 1,9 \\
\hline $\begin{array}{l}\text { zbyt rutynowe podejście pielęgniarki, może większa selekcja przy } \\
\text { zatrudnieniu, może szkolenie dla pielęgniarek przez psychologa }\end{array}$ & 1 & 1,9 \\
\hline $\begin{array}{l}\text { życzliwość i atmosfera w hospicjum jest najwyższej jakości, sądzę, że } \\
\text { ciągła obecność } 1-2 \text { wolontariuszy na oddziale usprawnia prace } \\
\text { pielęgniarkom, dlatego byłoby dobrze gdyby ktoś z nich był }\end{array}$ & 1 & 1,9 \\
\hline brak odpowiedzi & 32 & 61,5 \\
\hline Razem & 52 & 100,0 \\
\hline
\end{tabular}

Źródło: opracowanie własne

Warto się nad nimi zastanowić pomimo faktu, że są to pojedyncze opinie wolontariuszy.

\section{Wnioski}

Na podstawie przeprowadzonych badań i analizie uzyskanych wyników wysunięto następujące wnioski:

1. Główny wpływ na podnoszenie jakości opieki na oddziale stacjonarnym hospicjum ma pielęgniarka. Ze względu na to, że właśnie ona poświęca choremu najwięcej czasu, potrzebne jest jej wsparcie psychologa celem uniknięcia wypalenia zawodowego. Opieka jest wystarczająca, fachowa odpowiedniej jakości.

2. Opieka lekarska na oddziale stacjonarnym hospicjum jest wystarczająca, fachowa, odpowiedniej jakości.

3. Opieka duchowa na oddziale stacjonarnym hospicjum jest wystarczająca, fachowa, odpowiedniej jakości.

4. Opieka psychologa na oddziale stacjonarnym hospicjum jest wystarczająca, fachowa, odpowiedniej jakości, w zdecydowanej jednak większości korzystają z niej osoby wykształcone należałoby włożyć więcej wkładu w edukację zarówno samych 
chorych jak i ich rodzin, osób z wykształceniem niższym, celem poprawy jakości życia chorych..

5. Opieka rehabilitanta na oddziale stacjonarnym hospicjum jest wystarczająca, fachowa, odpowiedniej jakości, jednak z powodu specyfiki oddziału oraz ciężkości stanu chorych korzysta z tej opieki niewielu chorych.

6. Opieka wolontariusza jest odpowiedniej jakości, jednak potrzeba więcej szkoleń oraz selekcji podczas przyjmowania na wolontariusza.

7. Objawy chorobowe są dostatecznie i szybko łagodzone.

\section{Zalecenia dla praktyki pielęgniarskiej}

Opieka nad chorym $w$ terminalnej fazie choroby nowotworowej stanowi olbrzymie wyzwanie zarówno dla personelu medycznego jak i dla jego rodziny.

Znajomość idei opieki paliatywnej i przestrzeganie jej zasad stanowczo podnoszą jakość tej opieki. Dlatego pogłębianie wiedzy, nauka zachowań $\mathrm{w}$ stosunku do chorych i ich rodzin, a także ich edukacja są istotą uzyskania wysokiej jakości opieki sprawowanej przez personel medyczny.

\section{Bibliografia/Bibliography:}

1. Bishop G.: Psychologia Zdrowia. Wydawnictwo Astrum, Wrocław 2000.

2. Biernat W.: Podstawy genetyki molekularnej nowotworów [w:] Kordek R. (red.) Onkologia podręcznik dla studentów i lekarzy. Via Medica, Gdańsk 2007;7.

3. Meder J.: Od 5 do 10 procent chorób nowotworowych jest uwarunkowana genetycznie, http://www.monej.pl/ archiwum/wiadomości 2011- 03- 12. 
4. Krajnik M. Buczkowski K.: Definicja i filozofia opieki paliatywnej [w:] Buczkowski K. Krajnik M. (red.)Opieka paliatywna. Wyd. Lek. PZWL, Warszawa 2009; 10.

5. Miler J. Zgorzelak B.: Laureaci Złotego Stetoskopu. Biuletyn Informacyjny. Okręgowa Izba Pielęgniarek Położnych. 2010; (2): 2627.

6. Tanneberger S.: Opieka paliatywna w zaawansowanej chorobie nowotworowej [w:] Catane R. i inni (red.) Podręcznik postępowania w zaawansowanej chorobie nowotworowej. MediPage, Warszawa $2007 ; 5,6-7$.

7. Krasuska M. i wsp.: Wsparcie pacjenta i rodziny $\mathrm{w}$ chorobie, cierpieniu i śmierci. Psychoonkologia 2002; 6, (3): 65, 67, 67 - 69.

8. Adamczyk A. i wsp.: Opieka paliatywna. Wyd. Lek. PZWL, Warszawa 2009.

9. De Walden- Gałuszko K., Majkowicz M.: Model oceny jakości opieki paliatywnej realizowanej w warunkach stacjonarnych. Akademia Medyczna, Gdańsk 2001.

10. Trzebiatowska I.: Satysfakcja jako element oceny jakości opieki. [w:] de Walden- Gałuszko, Majkowicz (red.) Ocena jakości opieki paliatywnej w teorii i praktyce. Akademia Medyczna, Gdańsk $2001 ; .20$.

11. Lecouterier J. ,Jacoby A.: Lay carers satisfaction with community palliative care: results of postal survey. Palliat. Med.,13, s. 275 - 283.

12. Krawczyk M.: Mapa Kujawsko-Pomorskiego wolontariatu: Biuro Doradztwa Inwestycyjnego „Europejczyk”, Bydgoszcz 2010, s. 6 - 13

13. Mieszkuć -Mieszkowska Cz.: Hospicjum im. J. Popiełuszki informator. Pejzaż 2009 s. 5- 21, 31- 32. 
14. Pyszora A.: Efektywność fizjoterapii stosowanej u pacjentów cierpiących $\mathrm{z}$ powodu zmęczenia związanego $\mathrm{z}$ choroba nowotworową. Medycyna Paliatywna w Praktyce. 2008 2; (4): 164 165.

15. Davis M.P., Khoshknabi D., Yue G.H.: Mangementof fatigue in cancer patients.Curr. Pain and Headache Reports 2006; 10:260 - 269.

16. Donald G., McNail Jr., Palliative Care Extends Life, Study Finds, http://www.nytimes.com/2010/08/19/health/19care.html?ref=ne wenglandjournalofmedicine, 30.04.2011.

17. Przyłuska-Fiszer A., Wójcik A.: Problemy metodologiczne badań naukowych w opiece paliatywnej. Diametros 2009, 19: 119-131.

18. Oliver D.: Jak działa zespół interdyscyplinarny? Polska Medycyna Paliatywna. 2003; 3 (2): 191 - 192. 